\title{
Overexpression of CRKII increases migration and invasive potential in oral squamous cell carcinoma
}

Shin-ichi Yamada, DDS, $\mathbf{P h D}^{\mathrm{a}}$, Souichi Yanamoto, DDS, $\mathbf{P h D}{ }^{\mathrm{a}}$, Goro Kawasaki, DDS, $\mathbf{P h D}^{\mathrm{a}}$, Satoshi

Rokutanda, DDS, $\mathrm{PhD}^{\mathrm{a}}$, Hisanobu Yonezawa, DDS, $\mathrm{PhD}^{\mathrm{a}}$, Akiko Kawakita, DDS ${ }^{\mathrm{a}}$, and Takayuki K.

Nemoto, $\mathbf{P h D} \mathbf{b}^{\mathbf{b}}$

Departments of ${ }^{a}$ Oral and Maxillofacial Surgery, Unit of Translational Medicine, and ${ }^{b}$ Oral Molecular

Biology, Unit of Basic Medical Sciences, Course of Medical and Dental Sciences, Nagasaki University

Graduate School of Biomedical Sciences

Key Words: CRKII, invasion, metastasis, RNA interference, oral squamous cell carcinoma

Running title: Overexpression of CRKII in oral squamous cell carcinoma 


\section{Abbreviations: OSCC, oral squamous cell carcinoma; CRK, CT10 regulator of kinase}

Correspondence: Shin-ichi Yamada, DDS, PhD

Department of Oral and Maxillofacial Surgery, Unit of Translational Medicine, Course of Medical and

Dental Sciences, Nagasaki University Graduate School of Biomedical Sciences

1-7-1 Sakamoto, Nagasaki 852-8588, Japan

Email: shinshin@nagasaki-u.ac.jp

Fax: + $81958197700 ;$ Tel: + 81958197698 


\section{Abstract}

CT10 regulator of kinase (CRK) was originally identified as an oncogene product of v-CRK in a CT10

chicken retrovirus system. Overexpression of CRKII has been reported in several human cancers. CRKII

regulates cell migration, morphogenesis, invasion, phagocytosis, and survival; however, the underlying

mechanisms are not well understood. In the present study, we evaluated the possibility of CRKII as an

appropriate molecular target for cancer gene therapy. The expression of CRKII in 71 primary oral

squamous cell carcinomas and 10 normal oral mucosal specimens was determined immunohistochemically,

and the correlation of CRKII overexpression with clinicopathological factors was evaluated.

Overexpression of CRKII was detected in 41 of 70 oral squamous cell carcinomas, the frequency being

more significant than in normal oral mucosa. In addition, CRKII overexpression was more frequent in

higher-grade cancers according to the T classification, $\mathrm{N}$ classification, and invasive pattern. Moreover,

RNAi-mediated suppression of CRKII expression reduced the migration and invasion potential of an oral

squamous cell carcinoma cell line, OSC20. Downregulation of CRKII expression also reduced the

expression of Dock180, p130Cas, and Rac1, and the actin-associated scaffolding protein cortactin. These

results indicate that the overexpression of CRKII is tightly associated with an aggressive phenotype of oral

squamous cell carcinoma. Therefore, we propose that CRKII could be a potential molecular target of gene therapy by RNAi-targeting in oral squamous cell carcinoma. 


\section{Introduction}

Oral squamous cell carcinoma (OSCC) is the most common malignant tumor of the head and neck region and accounts for more than $90 \%$ of cancers of the oral cavity[1]. The primary therapeutic modality for OSCC is surgery. Although recent advances in surgical techniques and anticancer agents have improved tumor regression and survival for patients with OSCC, wide surgical resection of OSCC causes inevitably various oral dysfunctions. Therefore, new treatment strategies are urgently needed.

The presence of neck lymph node metastasis is strongly related to a poor prognosis in squamous cell carcinoma of the head and neck[2-4]. Moreover, it has been reported that an alteration in the expression of adhesion-related molecules is associated with poor prognosis in OSCC patients[5-8].

CRK is an adaptor family member of proteins mostly composed of SH2 and SH3 domains known to mediate protein-protein interactions, and plays an important role in intracellular signal transduction[9-11]. CRK was originally isolated as the oncogene product of v-CRK in a CT10 chicken retrovirus. Its cellular homologues have been isolated from various species[12,13]. Cellular homologues of v-CRK include the c-CRK gene, which produces two alternatively spliced protein products: CRKI (28 kDa) and CRKII (40 $\mathrm{kDa})[13,14]$. The ubiquitous expression of CRK is observed in embryos and adults[13.] In addition, the overexpression of CRK in malignant neoplasmas[15], including glioblastomas[16] and lung cancers[15,17], has been reported. CRKI/II mRNA expression is enhanced in lung tumors at more advanced stages and accompanies poor survival[17]. CRKI is composed of an SH2 and an SH3 domain, and CRKII has an 
additional SH3 domain[13]. The CRK-SH2 domain binds a specific phosphorylated tyrosine motif present in proteins involved in cell spreading, actin reorganization, and cell migration. Such CRK-SH2 binding proteins include the focal adhesion components, p130Cas and paxillin[18], growth factor receptor tyrosine kinases, and a docking protein Gab1, which is involved in epithelial dispersal and morphogenesis[19-21]. The $\mathrm{NH}_{2}$-terminal of the CRKII-SH3 domain constitutively interacts with proline-rich motifs present in proteins, including C3G, a nucleotide exchange factor for Rap1[22], Dock180, an exchange factor for Rac1[19,23], the Abl tyrosine kinase[24], tyrosine phosphatase[26], the p85 subunit of phosphatidylinositol 3-kinase[26], and the c-Jun- $\mathrm{NH}_{2}$-kinase[27]. The binding proteins of the $\mathrm{COOH}$-terminal of the SH3 domain are still poorly understood. CRKII has been identified as a mediator of cell migration associated with p130Cas and paxillin[28] as well as the Rac exchange factor Dock180[29]. Based on these interactions, the proposed roles of CRK include the regulation of cell migration, morphogenesis, invasion, phagocytosis, and survival[18]. However, the relationship between the expression of CRKII and the invasiveness and metastatic potential of cells remains unknown for OSCC. In this study, we examined CRKII expression in OSCC immunohistochemically, and then determined the clinicopathological significance of CRKII expression in relation to various parameters, such as patient characteristics and histopathological findings. We also performed siRNA analysis to assess whether CRKII could be a potent molecular target for cancer gene therapy of OSCC. 


\section{Materials and Methods}

\subsection{Patients}

Paraffin-embedded sections were obtained from biopsy specimens of 71 patients with OSCC who underwent radical surgery in our department. Tumor stage was classified according to the TNM classification of the International Union Against Cancer, histological differentiation was defined according to the WHO classification, and invasion pattern was determined according to Bryne's classification[30]. As controls, samples of normal oral epithelium were obtained after informed consent from 10 patients undergoing routine surgical removal of their third molars.

\subsection{Cell lines}

Basically, we examined the expression of CRKII in the seven OSCC cell lines (Ca9-22, SAS, SCC25, OSC20, HSC2, HSC3, and HSC4). Among them, the OSC 20 cell line expressed CRKII most strongly (date not shown). Therefore, we used the OSC20 cell line for our experiments. A human OSCC cell line (OSC20) was obtained from the Human Science Research Resource Bank (Osaka, Japan). The cells were cultured under conditions recommended by their depositors.

\subsection{Immunohistochemical staining and evaluation}

Serial 4- $\mu \mathrm{m}$-thick specimens were taken from tissue blocks. Sections were deparaffinized in xylene, 
soaked in target retrieval solution buffer (Dako, Glostrup, Denmark), and then placed in an autoclave at

$121^{\circ} \mathrm{C}$ for 5 min for antigen retrieval. Endogenous peroxidase was blocked by incubation with $0.3 \% \mathrm{H}_{2} \mathrm{O}_{2}$

in methanol for $30 \mathrm{~min}$. Immunohistochemical staining was performed using the Envision system

(Envision+, Dako, Carpinteria, CA). The primary antibody used was directed against CRKII (H-53, Santa

Cruz Biotech, Inc, CA, USA). The sections were incubated with the primary antibody overnight at $4^{\circ} \mathrm{C}$.

Reaction products were visualized by immersing the sections in diaminobenzidine (DAB) solution, and the samples were counterstained with Meyer's hematoxylin and mounted. Negative controls were prepared by replacement of the primary antibody with phosphate-buffered saline. CRKII expression was defined as the presence of specific staining in the nucleus and cytoplasm of tumor cells. The immunoreactivity of CRKII was scored by staining intensity and immunoreactive cell percentage as follows[31-33]: staining index $0=$ tissue with no staining; $1=$ tissue with faint or moderate staining in $\leq 25 \%$ of tumor cells; $2=$ tissue with moderate or strong staining from $25 \%$ to $50 \%$ of tumor cells; 3 = tissue with strong staining in $\geq 50 \%$ of tumor cells. Overexpression of CRKII was defined as staining index $\geq 2$.

\subsection{RNA isolation and semiquantitative reverse transcription-polymerase chain reaction (RT-PCR)}

Total RNA was isolated with TRIzol Reagent (Invitrogen, Carlsbad, CA, USA) and first-strand cDNA was synthesized from $1 \mu \mathrm{g}$ of total RNA using Oligo d (T) primer (Invitrogen) and ReverTra Ace (Toyobo, Osaka, Japan). For PCR analysis, Taq DNA polymerase was used to amplify cDNA (Takara, Otsu, Japan). 
Glyceraldehyde-3-phosphate dehydrogenase (GAPDH) was used as the endogenous expression standard.

Each PCR program involved a 3-min initial denaturation step at $94^{\circ} \mathrm{C}$, followed by 25 cycles (for CRKII),

or 18 cycles (for GAPDH) at $94^{\circ} \mathrm{C}$ for $30 \mathrm{~s}, 55^{\circ} \mathrm{C}$ for $30 \mathrm{~s}$, and $72^{\circ} \mathrm{C}$ for $1 \mathrm{~min}$, on a PCR Thermal Cycler

MP (Takara). Primer sequences were as follows: 5'-TCTCAGGCAGTGCAAATCAC-3' for CRKII (F);

5'-CGCTCCATACAATGAAAGCA-3' for CRKII (R); 5'-ATGTCGTGGAGTCTACTGGC-3' for GAPDH

(F); and 5'-TGACCTTGCCCACAGCCTTG-3' for GAPDH (R). The amplified products were separated

by electrophoresis on ethidium bromide-stained $2 \%$ agarose gels. Band intensity was quantified by Image J

software.

\subsection{Wound healing assay}

Cell migration was evaluated by a scratched wound-healing assay on plastic plate wells. In brief, cells

were grown to confluence and then wounded using a pipette tip. Three wounds were made for each sample,

and all were photographed at $0 \mathrm{~h}$ and subsequent time points. Cell migration was evaluated by measuring

the width of the wound at the identical position.

\subsection{Invasion assay}

A BioCoat Matrigel invasion chamber containing an internal chamber with an $8-\mu \mathrm{m}$ porous membrane bottom coated with Matrigel (Becton Dickinson, Bedford, MA) was used for the invasion assay. Six-well 
cell culture inserts and a 6-well multiwell companion plate were used for the experiment. The membranes were rehydrated with warm serum-free medium for $2 \mathrm{~h}$. The internal chamber was filled with $1.25 \times 10^{5}$ cells in medium containing $10 \% \mathrm{FBS}$ as a chemoattractant. Cells were incubated for $72 \mathrm{~h}$ at $37^{\circ} \mathrm{C}$ in a $5 \%$ $\mathrm{CO}_{2}$ atmosphere. After the incubation, noninvading cells were removed from the top of the wells with a cotton swab, and cells that transferred to the inverse surface of the membrane were subjected to Diff-Quick staining. Cells were counted under a microscope at $100 \times$ magnification. For the control, cells that passed through a control chamber without Matrigel were counted. All experiments were performed in triplicate, and cell numbers were counted in at least 4 fields/well. The ratio of the cell count that passed through the Matrigel chamber to the control cell count was defined as the invasion index, and was expressed as a percentage.

\subsection{RNA interference (RNAi)}

The CRKII siRNA sequences were 5'-GUAUCAGAAGGGAUAGGUATT-3' and 5'-UACCUAUCCCUUCUGAUACTT-3'. The scrambled control siRNA sequences were 5'-CGUAUGCGCGUACUCUAAUTT-3' and 5'-TTGCAUACGCGCAUGAGAUUA-3'. All sequences were submitted to the National Institutes of Health Blast program to ensure gene specificity. All siRNAs were purchased from Takara Bio Inc. (Otsu, Japan). Cells were transfected with double-stranded RNA using TransIT-siQUEST ${ }^{\circledR}$ transfection reagent (Mirus, Madison, WI, USA) 
according to the manufacturer's protocol. The OSC20 tongue cancer cell line was used for this experiment.

Briefly, $1.0 \times 10^{5}$ OSC20 cells were plated in each well of six-well plates and allowed to grow for $24 \mathrm{~h}$,

until they reached $50 \%$ confluence. Cells were then transfected with siRNA at a concentration of $200 \mathrm{nM}$

by using the transfection reagent in serum-free medium. Following $24 \mathrm{~h}$ of incubation, the medium was

replaced with serum-enriched medium and the cells were cultured for an additional $24 \mathrm{~h}$.

\subsection{Western blot analysis}

Cells were harvested by trypsinization, washed, and precipitated by centrifugation. The Mammalian

Cell Extraction Kit (BioVision Research Products, Mountain View, CA) was used for the extraction of

proteins. All subsequent manipulations were performed on ice. The cells were incubated in Extraction

Buffer Mix. The lysed cells were centrifuged at 15,000 rpm for $3 \mathrm{~min}$, and the resultant supernatant was

used as the cytoplasmic fraction. Protein concentration of each sample was measured with the micro-BCA

protein assay reagent (Pierce Chemical Co., Rockford, USA). Samples were denatured in SDS sample

buffer and loaded onto $12.5 \%$ polyacrylamide gels. After electrophoresis, the proteins were transferred

onto polyvinylidine difluoride membranes and immunoblotted with either anti-CRKII (H-53, Santa Cruz

Biotech), anti-p130 Cas (8G4-E8, Millipore, MA, USA), anti-Dock180 (H-4, Santa Cruz Biotech),

anti-Rac1 (102, BD Transduction Lab., CA, USA), or anti-cortactin (H-191, Santa Cruz Biotech, Inc., CA,

USA). Incubation with a horseradish peroxidase-conjugated secondary antibody (ECL antimouse IgG, 
Amersham Biosciences, Piscataway, $\mathrm{NJ} ; 0.01 \mu \mathrm{g} / \mathrm{ml}$ ) was performed, and signals were visualized with an

ECL Kit (Amersham Pharmacia Biotech, Buckinghamshire, UK).

\subsection{Statistical analysis}

Statistical analysis was performed using StatMate ${ }^{\circledR}$ (ATMS Co., Tokyo, Japan). The correlation between CRKII expression and the clinicopathological features was assessed by Fischer's exact test.

Continuous data are given as the means \pm standard deviation. Data sets were examined by one-way

analysis of variance (ANOVA) followed by Scheffe's post-hoc test. Survival analysis was carried out with

Kaplan-Meier curves and the related log-rank tests. $\mathrm{P}$ values less than 0.05 were considered significant 


\section{Results}

\subsection{Correlation between CRKII expression and clinicopathological features}

Immunohistochemistry with an anti-CRKII polyclonal antibody was performed on 71 patients with

oral squamous cell carcinoma. Representative immunohistochemical stainings are shown in Figure 1.

Overexpression of CRKII was undetectable in normal epithelium (date not shown). In the squamous cell

carcinoma cells, strong CRKII staining was located at the invasive front and the diffuse invasive area

(Fig.1D). Indeed, CRKII overexpression was recognized more frequently in OSCC (49 of $71,68.1 \%$ ) than in normal oral epithelium $(0$ of $10,0 \% ; \mathrm{p}<0.05)$. Furthermore, overexpression of CRKII was more frequent in cancers with higher grades according to the $\mathrm{T}$ classification (T 3/4 vs. 1/2; $\mathrm{p}<0.05), \mathrm{N}$ classification $(\mathrm{N}$ $3 / 4$ vs. $1 / 2 ; p<0.05$ ), and invasive pattern (grade $3 / 4$ vs. $1 / 2 ; p<0.001$, Table 1 ).

These findings strongly suggest that CRKII overexpression is a potent predictor of survival.

\subsection{Correlation between CRKII expression and survival analysis}

The 5-year survival rates according to CRKII expression and other clinicopathological features

were determined. There was a tendency of coupling between lower survival in patients and CRKII

overexpression, as seen in the $\mathrm{T}$ classification, $\mathrm{N}$ classification, and invasive pattern. The association was significant by the log rank test (Fig. 2). These findings also strongly suggest that CRKII overexpression is a potent predictor of survival. 


\subsection{Effect of CRKII on the migration and invasion of OSC20 cells}

Cell migration and invasion are basic characteristics of tumor metastasis. To determine the effect

of CRKII on the migration and invasion potential of cells, we transfected OSC20 cells with CRKII siRNA

and performed wound healing and Matrigel invasion assays. Transfection with CRKII siRNA significantly decreased CRKII mRNA and protein levels, compared with that of non-transfected cells and cells

transfected with scrambled siRNA (Fig. 3A, B). The induced downregulation of CRKII expression resulted in a $64.3 \%$ decrease in healing rate compared with the controls at $36 \mathrm{~h}$ after wounding (Fig. 3C).

Concomitantly, the invasion index of OSC20 cells decreased significantly from $92.4 \%$ and $91.7 \%$ in cells treated with vehicle alone and scrambled siRNA, respectively, to $30.3 \%$ in those transfected with CRKII siRNA (Fig. 3D). Therefore, downregulation of CRKII expression by siRNA drastically suppresses the mobility of OSC20 cells in vitro.

\subsection{Effect of decreasing CRKII expression on CRKII-p130Cas signaling}

Dock180 is reported to positively regulate signaling of integrins with CRKII-p130Cas complexes at focal adhesions[29]. Phosphorylated p130Cas interacts with CRK, which in turn binds to Dock180, an unconventional Rac-guanine nucleotide exchange factor that activates Rac1[34-38]. The p130Cas-CRK complex is reported to trigger actin polymerization by a Rac-independent mechanism[29]. Cortactin is an actin-associated scaffolding protein that binds and activates the actin-related protein (Arp) 2/3 complex, 
and regulates branched actin networks in the formation of dynamic cortical actin-associated

structures $[39,40]$. Cortactin and CRK cooperate to trigger actin polymerization during Shigella invasion of epithelial cells[41]. We therefore examined the effect of CRKII on the integrin-stimulated

Dock180-CRKII-p130Cas signaling pathway. CRKII-targeted siRNA transfection of OSC20 cells

significantly decreased p130Cas and Dock180, and Rac1 expression levels (Fig. 4). Moreover, the

CRKII-targeted siRNA transfection also decreased cortactin expression (Fig. 4). These results suggest that downregulation of CRKII induces the suppression of integrin-stimulated signaling pathways that govern the formation of focal adhesion and cortactin-mediated regulation of branched actin networks in OSCC. 


\section{Discussion}

CRK has been reported to regulate cytoskeletal reorganization by integrin stimulation, and thereby

modulate cell motility and adhesion[15]. The SH2 domain of CRK binds a phosphorylated tyrosine residue in the YXXXP motif of p130Cas and paxillin, the components of focal contacts[18]. The SH3 domain of CRK binds to DOCK180, which is reported to activate Rac regulation of cytoskeketal movement such as engulfment[19,23,29,34,42]. Increased CRKII activity suppresses apoptosis, induces lamellipodia formation and cell spreading in migratory cells[43], and encourages anchorage-independent growth[28]. It has been reported that increased expression of CRKI/II at the mRNA and protein level is observed in various cancers[15], including glioblastomas[16] and lung cancers[15,17]. In lung adenocarcinoma, $\mathrm{CRKI} / \mathrm{II}$ mRNA expression is predominantly increased at more advanced stages and is associated with poor survival[17]. In the present study, we reveal that CRKII overexpression strongly correlates with cancers of higher grades in T classification, $\mathrm{N}$ classification, and invasive pattern. Additionally, Kaplan-Meier analysis revealed a significant association of CRKII expression with 5-year survival rates (log-rank, $\mathrm{p}<0.05$ ), similar to the $\mathrm{T}$ classification, $\mathrm{N}$ classification , and pattern of invasion, respectively. There were no significant differences in the correlation between CRKII overexpression clinical factors in the analysis using multivariate statistics. Because of uneven case distributions of CRKII overexpression negative and positive groups in T classification and N-classification, the correlation between CRKII overexpression and clinical factors may be affected. However, our findings are basically consistent with 
the results of a previous study that demonstrates the close relationship between elevated CRK levels and poorer survival in lung adenocarcinoma patients ${ }^{17}$. Importantly, our study further suggests that CRKII expression levels could be a prognostic factor in OSCC patients.

Cell motility is a complex event dependent on the coordinated remodeling of the actin cytoskeleton, on regulated assembly, and on turnover of focal adhesion[44]. In this context, it seemed important to demonstrate that CRKII expression could be associated with the migration and invasion capacity of the human tongue squamous cell carcinoma cell line, OSC20. Our study shows that de novo expression of CRKII raises the migration and invasion potential of tongue squamous cell carcinoma cells. Moreover, immunohistochemical analysis of CRKII revealed strong positivity at the invasive front of the diffuse invasion pattern. However, the mechanism by which CRKII increases the invasive potential remains unclear. The molecular complex composed of paxillin-CRKII-Dock180 is reported to govern one major aspect of cell migration, which is the activation of Rac1[45]. Subsequently, Rac1 controls actin cytoskeletal dynamics and integrin adhesions that are essential for lamellipodium extension during cell migration[46,47]. The expression of farnesylated Dock180 induced the spreading of spindle-shaped NIH3T3 cells, which suggests that Dock180 may be involved in cytoskeletal reorganization[42]. In lung cancer cell lines, the expression of Dock180 is reported to correlate with growth rate[15]. As p130Cas contains multiple binding motifs for SH2 and SH3 domains, it localizes at focal adhesions and becomes tyrosine-phosphorylated upon integrin stimulation[48-50]. Tyrosine-phosphorylation of p130Cas recruits 
CRKII to focal adhesions[51,52]. The formation of CRKII-p130Cas complexes and their

hyperphosphorylation is upregulated by Dock180[29]. Dock180 overexpression induces accumulation of p130Cas, Dock180, and CRKII at focal adhesions[29]. Our results suggest that the suppression of CRKII may cause the inhibition of the formation of CRKII-p130Cas complexes, which result in the effects on the binding of DOCK180 to SH3-domain of CRKII and additional Rac1 binding to those complex in the integrin-stimulated signaling pathways that govern the formation of focal adhesion and cortactin-mediated regulation of branched actin networks in OSCC.

Additionally, it has been reported that CRKII performs a critical role in promoting the epithelial-mesenchymal-like transition in epithelial cells, and that stable overexpression of CRKII activates the downstream effectors, Rac1 and Rap, and promotes the spreading of MDCK (normal kidney) cells[53]. CRKII stimulates the breakdown of epithelial adherens junctions by inhibiting membrane accumulation of E-cadherin and $\beta$-catenin, and promotes cell dispersal in moderately differentiated breast cancer cell lines[53]. Therefore, our data demonstrating the inhibition of the formation of CRKII-Dock180-p130Cas complexes by the reduction of CRKII, strongly suggests that CRKII is involved in promoting the epithelial-mesenchymal-like transition in OSCC. The interaction of p130Cas and paxillin with CRK mediates signal transmission from extracellular stimulation to the reorganization of the actin cytoskeleton[28,54]. CRK integrates multiple signals that could selectively lead to interactions between CRK and paxillin, CRK and p130Cas, or Rac activation. In turn, Rac can mediate Arp2/3-dependent actin 
polymerization through its interaction with IRSp53 and the WASP-family protein, WAVE[55]. CRK was shown to directly interact with tyrosine-phosphorylated cortactin and to mediate cortactin-dependent actin polymerization required for Shigella uptake[41]. The CRK-cortactin complex has been reported to play a major role in actin polymerization downstream of tyrosine kinase signaling[41]. In this report, downregulation of CRKII also decreased the expression levels of Rac1 and cortactin in the OSC20 cell line, which indicates that the CRK-cortactin complex may also play a major role in actin polymerization in OSCC.

In summary, we demonstrate the significance of CRKII overexpression and its potential as a prognostic factor for OSCC as well as the possibility of an epithelial-mesenchymal-like transition in OSCC. RNAi technology is a specific and powerful tool to turn off the expression of oncogenic target genes[56]. In oral cancers, the possibility of RNA-mediated gene therapy has been reported[57,58]. We successfully applied RNA silencing to inhibit the expression of CRKII, and thereby decreased the invasive potential of OSCC. Thus, we propose that RNAi-mediated gene silencing of CRKII could be a useful modality for OSCC treatment in the future. 


\section{Acknowledgements}

We would like to thank Prof. Tohru Ikeda and Associate Prof. Shuichi Fujita of the Department of

Oral Pathology and Bone Metabolism, Unit of Basic Medical Sciences, Course of Medical and Dental

Sciences, Nagasaki University Graduate School of Biomedical Sciences for their help in preparing this

manuscript.

This study was supported in part by Grant 18791508 from the Ministry of Education, Culture, Sports,

Science and Technology, Japan.

Funding: None

Competing interests: None declared

Ethical approval: Not required 


\section{Reference}

[1] Mao L, Hong WK, Papadimitrakopoulou VA., Focus on head and neck cancer, Cancer Cell 5(2004)

$311-316$.

[2] Hicks WL Jr, North JH Jr, Loree TR, Maamoun S, Mullins A, Orner JB,. et al. Surgery as a single modality therapy for squamous cell carcinoma of the oral tongue, Am J Otolaryngol 19 (1998) 24-28.

[3] Sessions DG, Lenox J, Spector GJ, Chao C, Chaudry OA. Analysis of treatment results for base of tongue cancer, Laryngoscope 113(2003) 1252-1261.

[4] González-García R, Naval-Gías L, Sastre-Pérez J, Rodríguez-Campo FJ, Muñoz-Guerra MF,

Usandizaga JL, et al. Contralateral lymph neck node metastasis of squamous cell carcinoma of the oral cavity: a retrospective analytic study in 315 patients. J Oral Maxillofac Surg 66(2008) 1390-1398.

[5] Ziober BL, Silverman SS Jr, Kramer RH. Adhesive mechanisms regulating invasion and metastasis in oral cancer. Crit Rev Oral Biol Med 12(2001) 499-510.

[6] Bánkfalvi A, Krassort M, Buchwalow IB, Végh A, Felszeghy E, Piffkó J. Gains and losses of adhesion molecules (CD44, E-cadherin, and beta-catenin) during oral carcinogenesis and tumour progression. J Pathol 198(2002) 343-351.

[7] Arora S, Kaur J, Sharma C, Mathur M, Bahadur S, Shukla NK,, et al. Stromelysin 3, Ets-1, and vascular endothelial growth factor expression in oral precancerous and cancerous lesions: correlation with microvessel density, progression, and prognosis. Clin Cancer Res 11(2005) 2272-2284. 
「8」 Yanamoto S, Kawasaki G, Yoshitomi I, Iwamoto T, Hirata K, Mizuno A. Clinicopathologic significance of EpCAM expression in squamous cell carcinoma of the tongue and its possibility as a potential target for tongue cancer gene therapy. Oral Oncol 43(2007) 869-877.

[9] Hanahan D, Weinberg RA.. The hallmarks of cancer. Cell, 100 (2000) 57-70.

[10] Clark EA, Brugge JS. Integrins and signal transduction pathways: the road taken, Science.

268(1995):233-239.

[11] Birge RB, Knudsen BS, Besser D, Hanafusa H. SH2 and SH3-containing adaptor proteins: redundant or independent mediators of intracellular signal transduction, Genes Cells. 1(1996):595-613.

[12] Mayer BJ, Hamaguchi M, Hanafusa H, A novel viral oncogene with structural similarity to phospholipase C. Nature. Mar 172(1988):272-275..

[13] Matsuda M, Tanaka S, Nagata S, Kojima A, Kurata T, Shibuya M. Two species of human CRK cDNA encode proteins with distinct biological activities, Mol Cell Biol. 12(1992):3482-3489.

[14] Feller SM. Crk family adaptors-signalling complex formation and biological roles, Oncogene. 20(2001):6348-6371.

[15] Nishihara H, Tanaka S, Tsuda M, Oikawa S, Maeda M, Shimizu M, et al. Molecular and immunohistochemical analysis of signaling adaptor protein Crk in human cancers, Cancer Lett. 180(2002):55-61. 
[16] Takino T, Nakada M, Miyamori H, Yamashita J, Yamada KM, Sato H. CrkI adapter protein

modulates cell migration and invasion in glioblastoma. Cancer Res. 63(2003):2335-2337.

[17]. Miller CT, Chen G, Gharib TG, Wang H, Thomas DG, Misek DE, et al. Increased C-CRK

proto-oncogene expression is associated with an aggressive phenotype in lung adenocarcinomas, Oncogene.

22(2003):7950-7957.

[18]. Chodniewicz D, Klemke RL. Regulation of integrin-mediated cellular responses through assembly of

a CAS/Crk scaffold. Biochim Biophys Acta. 5(2004):63-76.

[19]. Lamorte L, Rodrigues S, Naujokas M, Park M. Crk synergizes with epidermal growth factor for epithelial invasion and morphogenesis and is required for the met morphogenic program. J Biol Chem.

277(2002):37904-37911.

[20. ]Garcia-Guzman M, Dolfi F, Zeh K, Vuori K. Met-induced JNK activation is mediated by the adapter protein Crk and correlates with the Gab1 - Crk signaling complex formation. Oncogene.

18(1999):7775-7786.

[21]. Maroun CR, Holgado-Madruga M, Royal I, Naujokas MA, Fournier TM, Wong AJ, et al. The Gab1

$\mathrm{PH}$ domain is required for localization of Gab1 at sites of cell-cell contact and epithelial morphogenesis downstream from the met receptor tyrosine kinase. Mol Cell Biol. 19(1999):1784-1799. 
[22]. Gotoh T, Hattori S, Nakamura S, Kitayama H, Noda M, Takai Y, et al. Identification of Rap1 as a target for the Crk SH3 domain-binding guanine nucleotide-releasing factor C3G. Mol Cell Biol.

15(1995):6746-6753.

[23]. Nolan KM, Barrett K, Lu Y, Hu KQ, Vincent S, Settleman J. Myoblast city, the Drosophila homolog of DOCK180/CED-5, is required in a Rac signaling pathway utilized for multiple developmental processes.

Genes Dev. 12(1998):3337-3342.

[24]. Feller SM, Knudsen B, Hanafusa H. c-Abl kinase regulates the protein binding activity of c-Crk.

EMBO J.13(1994):2341-2351.

[25]. Liu F, Hill DE, Chernoff J. Direct binding of the proline-rich region of protein tyrosine phosphatase 1B to the Src homology 3 domain of p130(Cas). J Biol Chem.271(1996):31290-31295.

[26]. Gelkop S, Babichev Y, Isakov N. T cell activation induces direct binding of the Crk adapter protein to the regulatory subunit of phosphatidylinositol 3-kinase (p85) via a complex mechanism involving the Cbl protein. J Biol Chem. 276(2001):36174-36182.

[27]. Friedl P, Wolf K. Tumour-cell invasion and migration: diversity and escape mechanisms. Nat Rev Cancer. 3(2003):362-374. 
[28]. Klemke RL, Leng J, Molander R, Brooks PC, Vuori K, Cheresh DA. CAS/Crk coupling serves as a

"molecular switch" for induction of cell migration. J Cell Biol. 140(1998):961-972.

[29]. Kiyokawa E, Hashimoto Y, Kurata T, Sugimura H, Matsuda M. Evidence that DOCK180 up-regulates signals from the CrkII-p130(Cas) complex. J Biol Chem.273(1998):24479-24484.

[30]. Bryne M, Boysen M, Alfsen CG, Abeler VM, Sudbø J, Nesland JM, Kristensen GB, et al. The invasive front of carcinomas. The most important area for tumour prognosis? Anticancer Res.

18(1998):4757-4764.

[31]. Fu L, Qin YR, Xie D, Chow HY, Ngai SM, Kwong DL, et al. Identification of alpha-actinin 4 and 67

$\mathrm{kDa}$ laminin receptor as stage-specific markers in esophageal cancer via proteomic approaches. Cancer.

110(2007):2672-2681.

[32]. Yamada S, Yanamoto S, Yoshida H, Yoshitomi I, Kawasaki G, Mizuno A, et al.

RNAi-mediated down-regulation of alpha-actinin-4 decreases invasion potential in oral squamous cell

carcinoma. Int J Oral Maxillofac Surg. 39(2010):61-67.

[33]. Yamada SI, Yanamoto S, Kawasaki G, Mizuno A, Nemoto TK. Overexpression of Cortactin

Increases Invasion Potential in Oral Squamous Cell Carcinoma. Pathol Oncol Res. 2010 Jan 13.

[34]. Albert ML, Kim JI, Birge RB. alphavbeta5 integrin recruits the CrkII-Dock180-rac1 complex for phagocytosis of apoptotic cells. Nat Cell Biol. 2(2000):899-905. 
[35]. Wu YC, Horvitz HR. C. elegans phagocytosis and cell-migration protein CED-5 is similar to human DOCK180. Nature. 392(1998):501-504.

[36]. Reddien PW, Horvitz HR. CED-2/CrkII and CED-10/Rac control phagocytosis and cell migration in Caenorhabditis elegans. Nat Cell Biol. 2(2000):131-136.

[37]. Brugnera E, Haney L, Grimsley C, Lu M, Walk SF, Tosello-Trampont AC, et al. Unconventional Rac-GEF activity is mediated through the Dock180-ELMO complex. Nat Cell Biol. 4(2002):574-582.

[38]. Côté JF, Vuori K. Identification of an evolutionarily conserved superfamily of DOCK180-related proteins with guanine nucleotide exchange activity. J Cell Sci. 115(2002):4901-4913.

[39]. Weed SA, Parsons JT. Cortactin: coupling membrane dynamics to cortical actin assembly. Oncogene. 20(2001):6418-6434.

[40].Daly RJ. Cortactin signalling and dynamic actin networks. Biochem J. 382(2004):13-25.

[41]. Bougnères L, Girardin SE, Weed SA, Karginov AV, Olivo-Marin JC, Parsons JT, et al. Cortactin and Crk cooperate to trigger actin polymerization during Shigella invasion of epithelial cells. J Cell Biol.

166(2004):225-235.

[42]. Hasegawa H, Kiyokawa E, Tanaka S, Nagashima K, Gotoh N, Shibuya M, et al. DOCK180, a major CRK-binding protein, alters cell morphology upon translocation to the cell membrane. Mol Cell Biol. 16(1996):1770-1776. 
[43]. Cheresh DA, Leng J, Klemke RL. Regulation of cell contraction and membrane ruffling by distinct signals in migratory cells. J Cell Biol. 146(1999):1107-1116.

[44]. Wehrle-Haller B, Imhof BA. Actin, microtubules and focal adhesion dynamics during cell migration.

Int J Biochem Cell Biol. 35(2003):39-50.

[45]. Vallés AM, Beuvin M, Boyer B. Activation of Rac1 by paxillin-Crk-DOCK180 signaling complex is antagonized by Rap1 in migrating NBT-II cells. J Biol Chem. 279(2004):44490-44496.

[46]. Etienne-Manneville S, Hall A. Rho GTPases in cell biology. Nature. 420(2002):629-635.

[47].Ridley AJ. Rho GTPases and cell migration. J Cell Sci. 114(2001):2713-2722.

[48]. Nojima Y, Morino N, Mimura T, Hamasaki K, Furuya H, Sakai R, et al. Integrin-mediated cell adhesion promotes tyrosine phosphorylation of p130Cas, a Src homology 3-containing molecule having multiple Src homology 2-binding motifs. J Biol Chem. 270(1995):15398-15402.

[49]. Nakamoto T, Sakai R, Honda H, Ogawa S, Ueno H, Suzuki T,et al.

Requirements for localization of p130cas to focal adhesions. Mol Cell Biol.17(1997):3884-3897.

[50]. Vuori K, Ruoslahti E. Tyrosine phosphorylation of p130Cas and cortactin accompanies integrin-mediated cell adhesion to extracellular matrix. J Biol Chem. 270(1995):22259-22262.

[51]. Vuori K, Hirai H, Aizawa S, Ruoslahti E. Introduction of p130cas signaling complex formation upon integrin-mediated cell adhesion: a role for Src family kinases. Mol Cell Biol. 16(1996):2606-2613. 
[52]. Nievers MG, Birge RB, Greulich H, Verkleij AJ, Hanafusa H, van Bergen en Henegouwen PM.

v-Crk-induced cell transformation: changes in focal adhesion composition and signaling. J Cell Sci. 110

( 1997):389-399.

[53]. Lamorte L, Royal I, Naujokas M, Park M. Crk adapter proteins promote an

epithelial-mesenchymal-like transition and are required for HGF-mediated cell spreading and breakdown

of epithelial adherens junctions. Mol Biol Cell. 13(2002):1449-1461.

[54]. Cheresh DA, Leng J, Klemke RL. Regulation of cell contraction and membrane ruffling by distinct signals in migratory cells. J Cell Biol. 146(1999):1107-1116.

[55]. Miki H, Yamaguchi H, Suetsugu S, Takenawa T. IRSp53 is an essential intermediate between Rac and WAVE in the regulation of membrane ruffling. Nature. 408(2000):732-735.

[56]. Tuschl T. Expanding small RNA interference. Nat Biotechnol. 20(2002):446-448.

[57]. Kudo Y, Kitajima S, Ogawa I, Kitagawa M, Miyauchi M, Takata T. Small interfering RNA targeting of $\mathrm{S}$ phase kinase-interacting protein 2 inhibits cell growth of oral cancer cells by inhibiting p27 degradation. Mol Cancer Ther. 4(2005):471-476.

[58]. Yanamoto S, Iwamoto T, Kawasaki G, Yoshitomi I, Baba N, Mizuno A. Silencing of the p53R2 gene by RNA interference inhibits growth and enhances 5-fluorouracil sensitivity of oral cancer cells. Cancer Lett. 223(2005):67-76. 


\section{Figure Legends}

Figure 1

Representative immunohistochemical staining of CRKII.

(A and C) H-E staining, and (B and D) immunohistochemical staining of CRKII(A and B: 100×

magnification, C and D: 40× magnification. Well-differentiated squamous cell carcinoma (A) demonstrates

strong CRKII expression (staining index of 3) and diffuse invasion (C). Well-differentiated squamous cell

carcinoma (B) demonstrates strong cytoplasmic expression in cancer nests, and intense staining is shown

in squamous cell carcinoma cells at the invasive front of the tumor (D).

Figure 2

Kaplan-Meier curves for 5-year survival analysis.

Kaplan-Meier curves for 5-year survival were examined about CRKII overexpression. The associations was significant using the log rank test (CRKII overexpression: overexpression $(+) /(-)$;

$\mathrm{p}<0.05)$ 
Figure 3

RNAi of CRKII in OSC20 cells.

OSC20 cells were transfected with either scrambled or CRKII siRNA. (A) After $72 \mathrm{~h}$, isolated total RNA was analyzed by RT-PCR for CRKII or GAPDH and (B) protein extracts were used for western blotting of CRKII or $\beta$-actin. (C) The wound healing process was photographed at $0,12,24$, and $36 \mathrm{~h}$ after wounding (left), and healing rates were determined as described in Materials and Methods; mock (closed circle), scrambled (open circle), and RNAi (square) (right). The graph shows a significant decrease in the wound healing rate in OSC20 cells treated with CRKII siRNA ( $p<0.001$ ). (D) Invasion of OSC20 cells (left) and the percentage of invaded cells (right) were determined as described in Materials and Methods. The graph shows a significant decrease in the invasion index of OSC20 cells treated with CRKII siRNA $(\mathrm{p}<0.001)$.

Figure 4

Western blot analysis of proteins modulated by the suppression of CRKII expression. OSC20 cells were transfected with either scrambled siRNA or CRKII siRNA. After $72 \mathrm{~h}$, proteins of whole cell lysates were analyzed by western blot analysis. Western blot analysis shows the decreased expression of Dock180, p130Cas, Rac1, and cortactin. 


\begin{tabular}{|c|c|c|c|}
\hline & $\begin{array}{l}\text { CRK II } \\
\qquad(-)\end{array}$ & $\begin{array}{l}\text { ession } \\
(+)\end{array}$ & p value \\
\hline $\begin{array}{l}\text { Normal epithelium } \\
\text { Squamous cell carcinoma }\end{array}$ & $\begin{array}{l}10 \\
22\end{array}$ & $\begin{array}{r}0 \\
49\end{array}$ & $\mathrm{p}<0.05$ \\
\hline $\begin{array}{ll}\text { Gender } & \text { Male } \\
& \text { Female }\end{array}$ & $\begin{array}{c}13 \\
9\end{array}$ & $\begin{array}{l}27 \\
22\end{array}$ & $p=0.753$ \\
\hline $\begin{array}{l}\leqq 60 \\
>60\end{array}$ & $\begin{array}{r}2 \\
20\end{array}$ & $\begin{array}{l}19 \\
30\end{array}$ & $\mathrm{p}<0.05$ \\
\hline $\begin{array}{r}\mathrm{T} \text { classification } \mathrm{T} 1+\mathrm{T} 2 \\
\mathrm{~T} 3+\mathrm{T} 4\end{array}$ & $\begin{array}{l}18 \\
4\end{array}$ & $\begin{array}{l}28 \\
21\end{array}$ & $\mathrm{p}<0.05$ \\
\hline $\begin{array}{ll}N \text { classification } & N 0 \\
& N 1+N 2\end{array}$ & $\begin{array}{r}21 \\
1 \\
\end{array}$ & $\begin{array}{l}35 \\
14 \\
\end{array}$ & $\mathrm{p}<0.05$ \\
\hline $\begin{array}{l}\text { Differentiation } \quad \text { Well } \\
\text { Moderate/Poor }\end{array}$ & $\begin{array}{r}17 \\
5\end{array}$ & $\begin{array}{r}44 \\
5\end{array}$ & $p=0.161$ \\
\hline $\begin{array}{l}\text { Pattern of invasion Grades1/2 } \\
\text { Grades3/4 }\end{array}$ & $\begin{array}{l}20 \\
2\end{array}$ & $\begin{array}{l}23 \\
26\end{array}$ & $\mathrm{p}<0.001$ \\
\hline
\end{tabular}

Table 1. Correlation of CRKII overexpression with clinicopathological features 


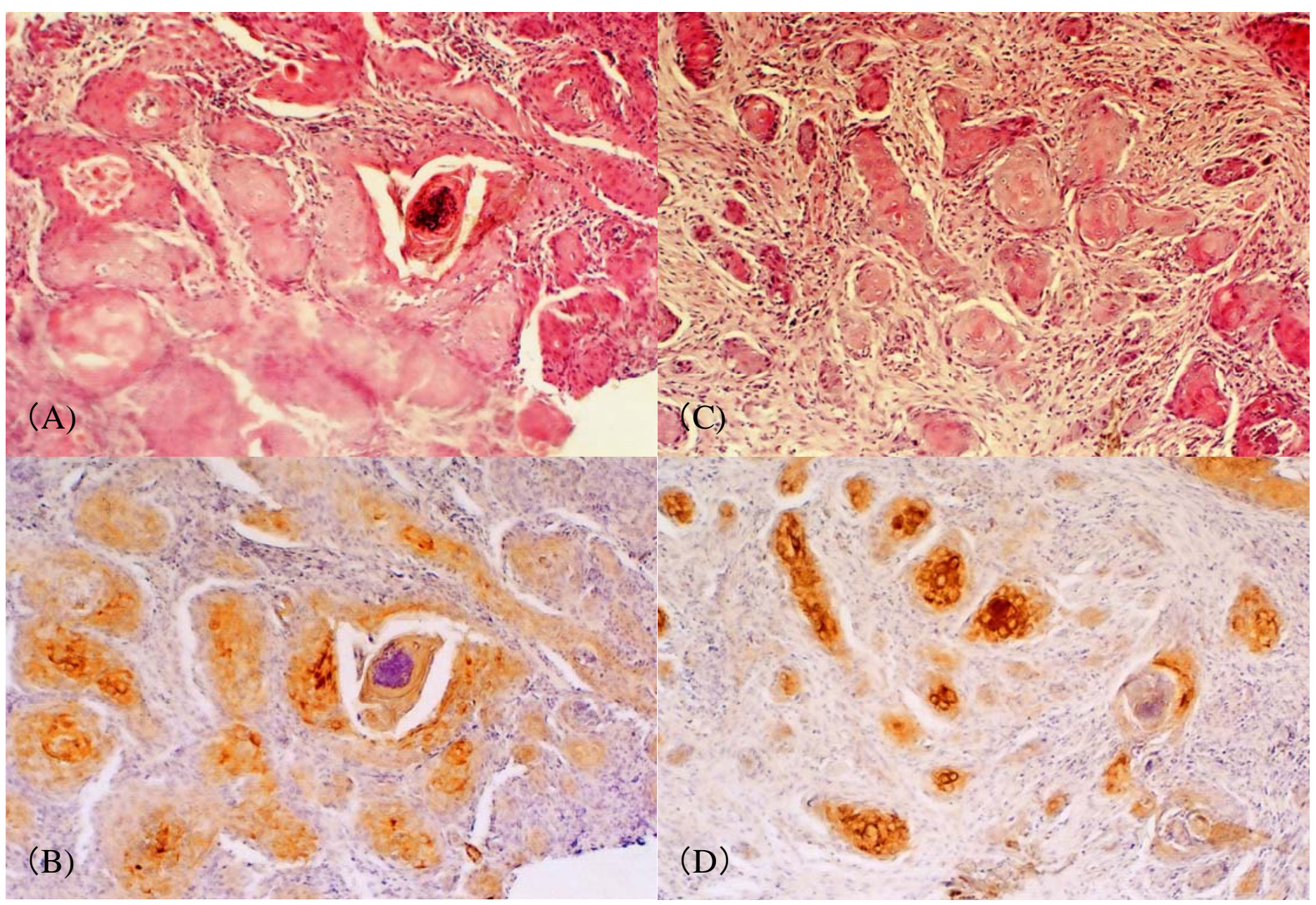

Fig. 1 


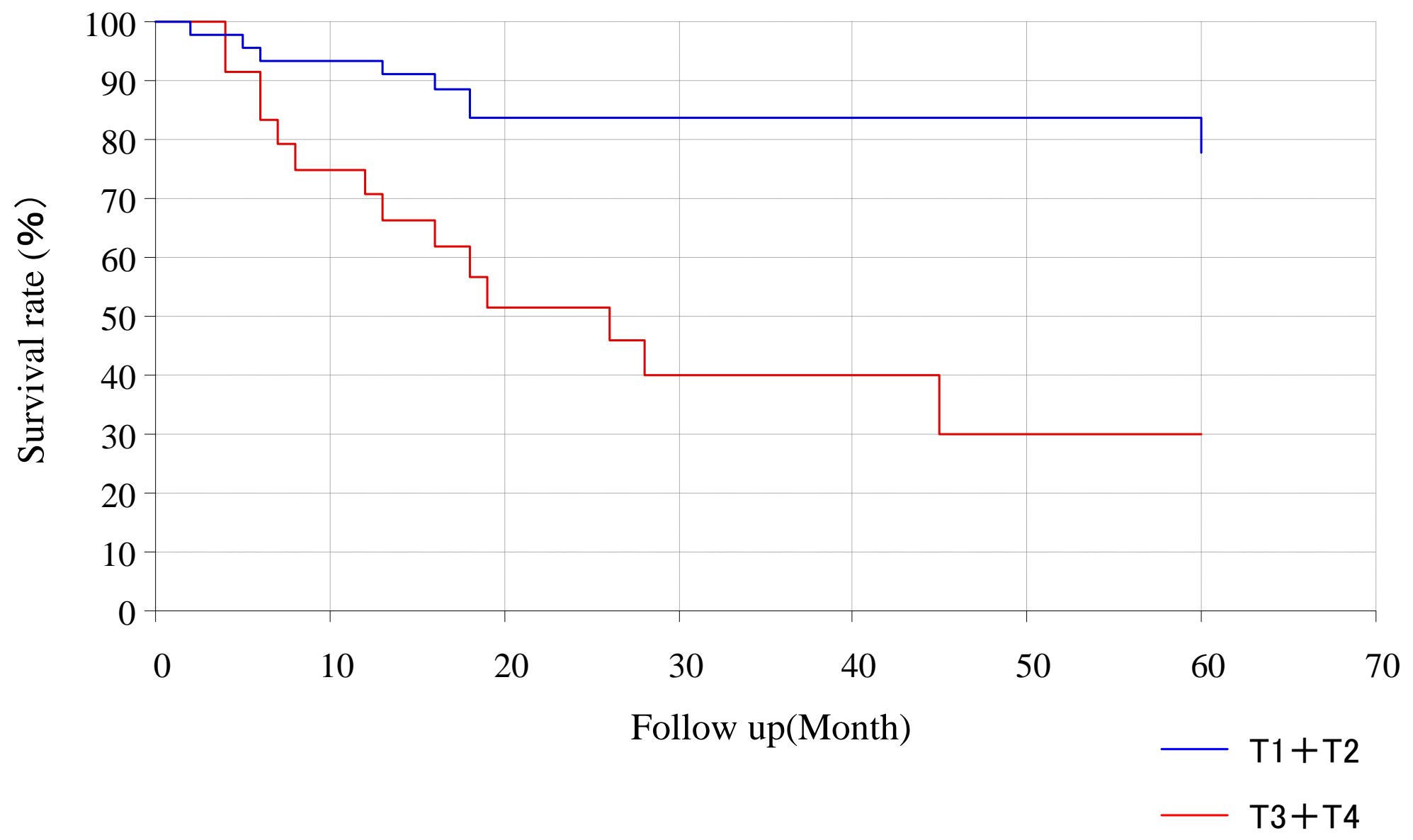

Fig. 2A 


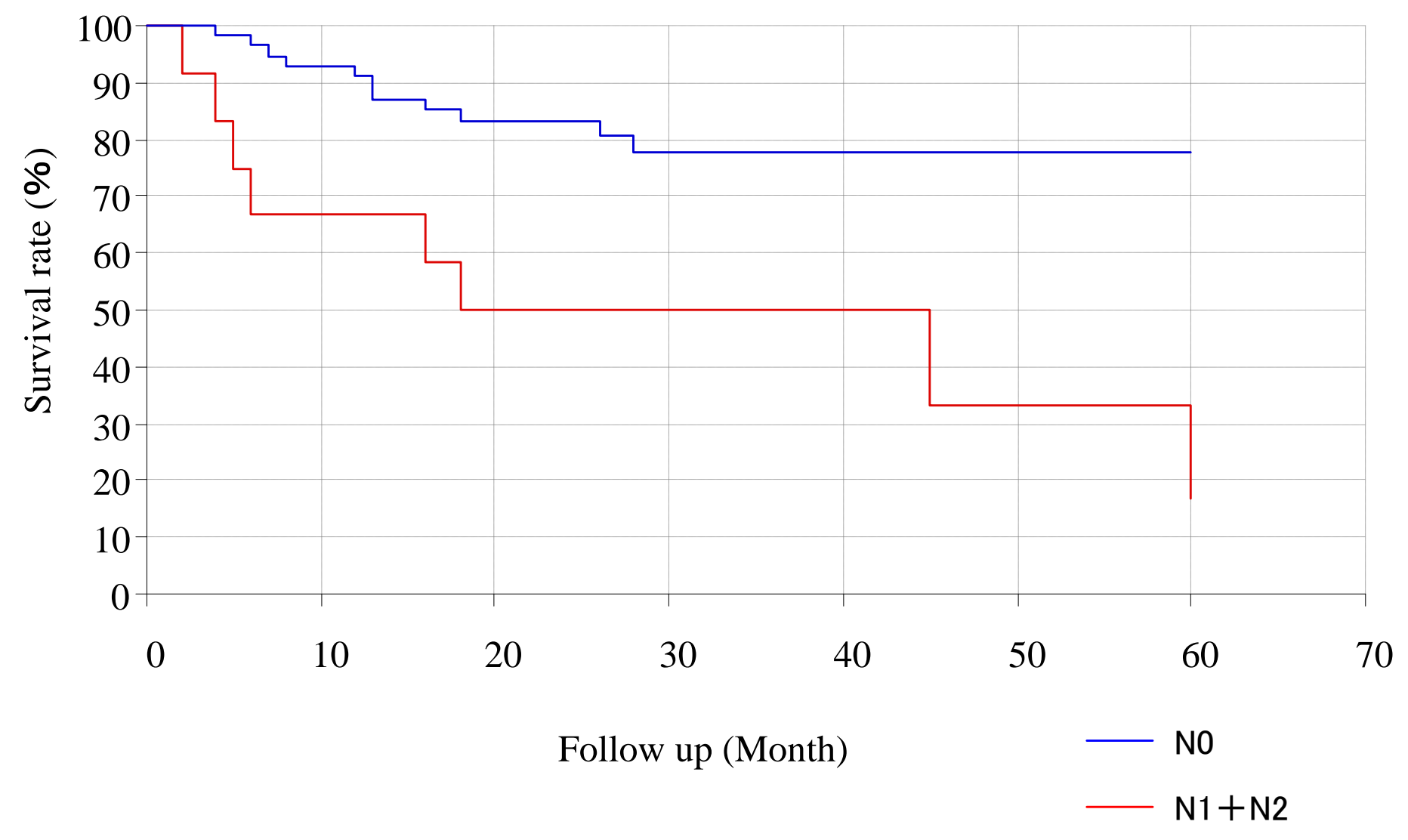

Fig. 2B 


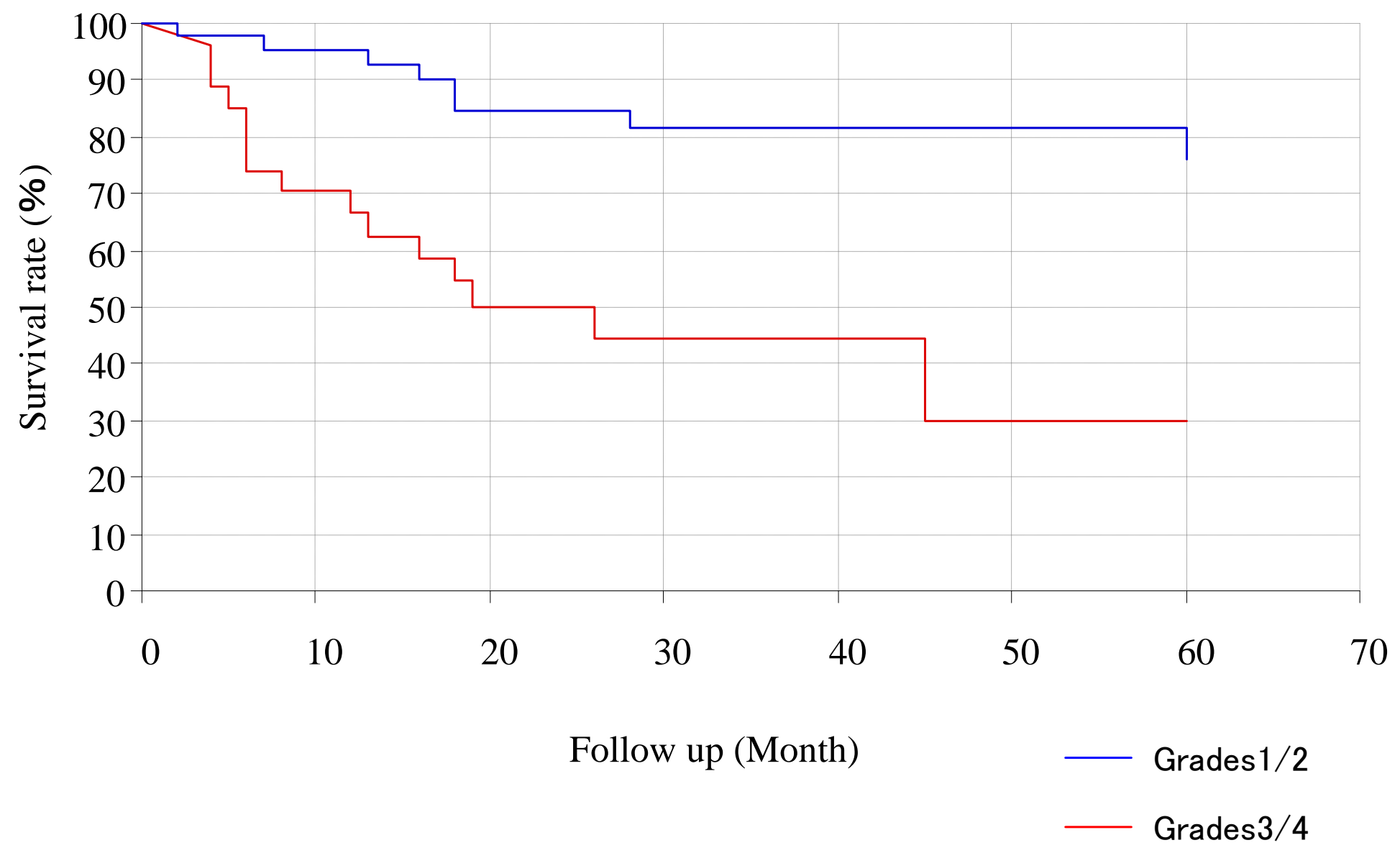

Fig. 2C 


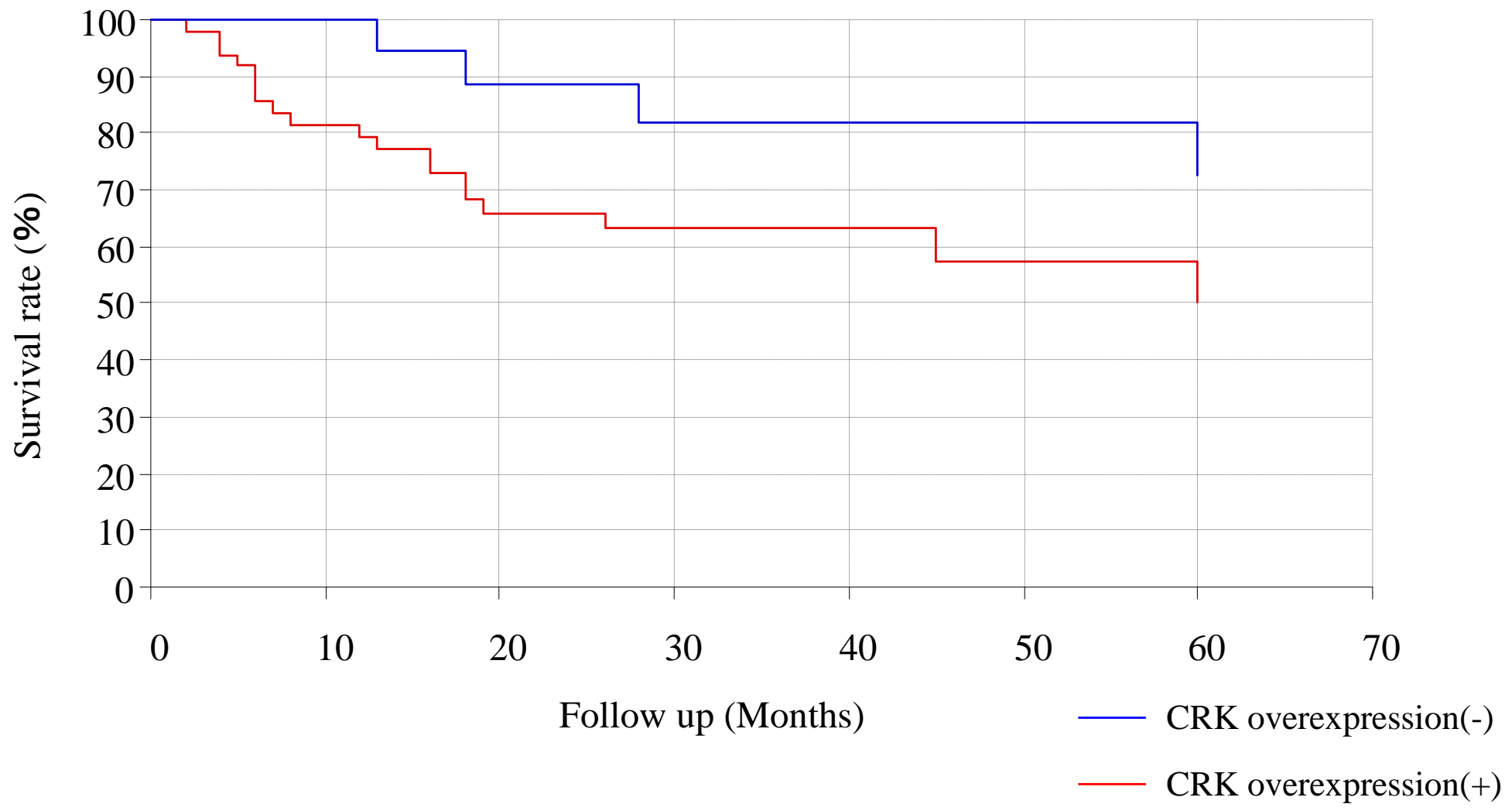

Fig. 2D 


\section{Mock RNAi scrambled \\ CRK II \\ GAPDH}

Fig. 3A 
Mock RNAi Scrambled

CRK II

$\beta$-actin

Fig. 3B 

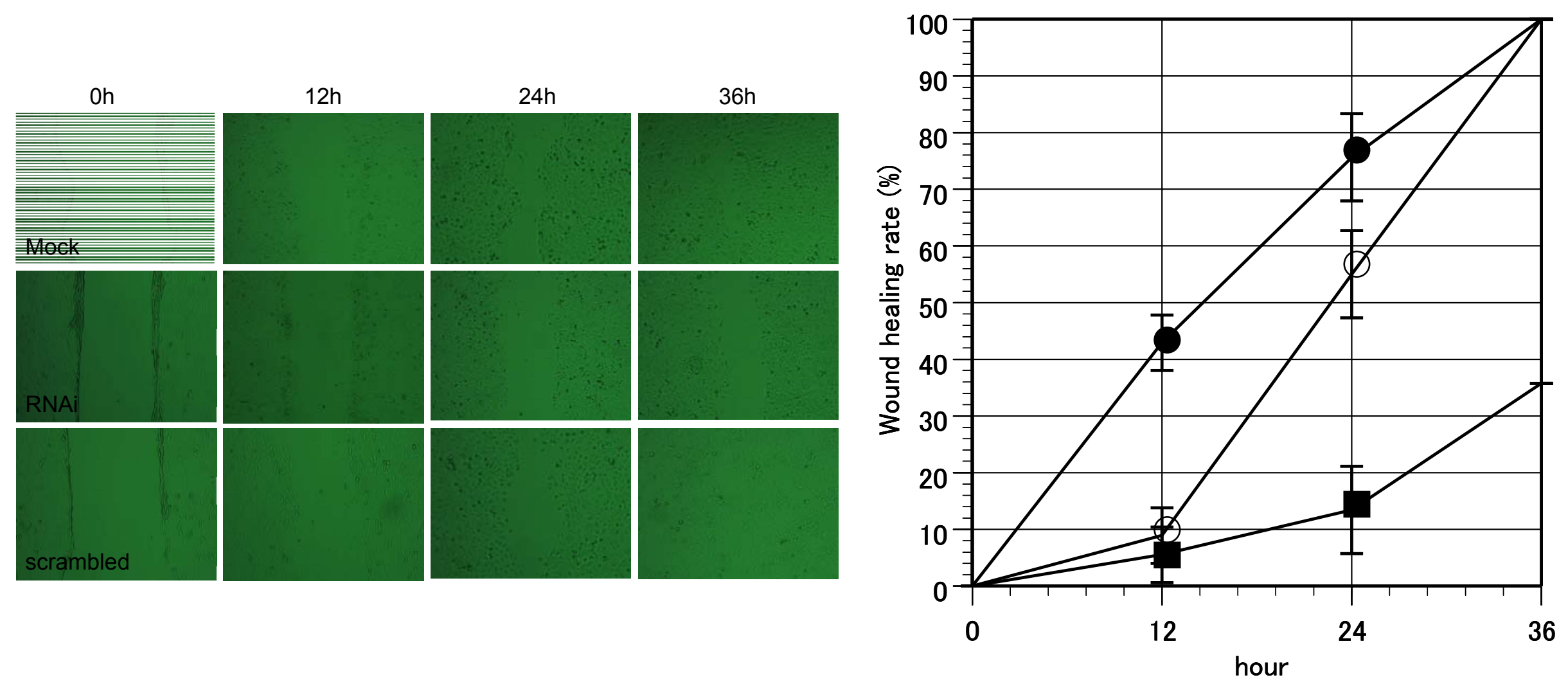

Fig. 3C 

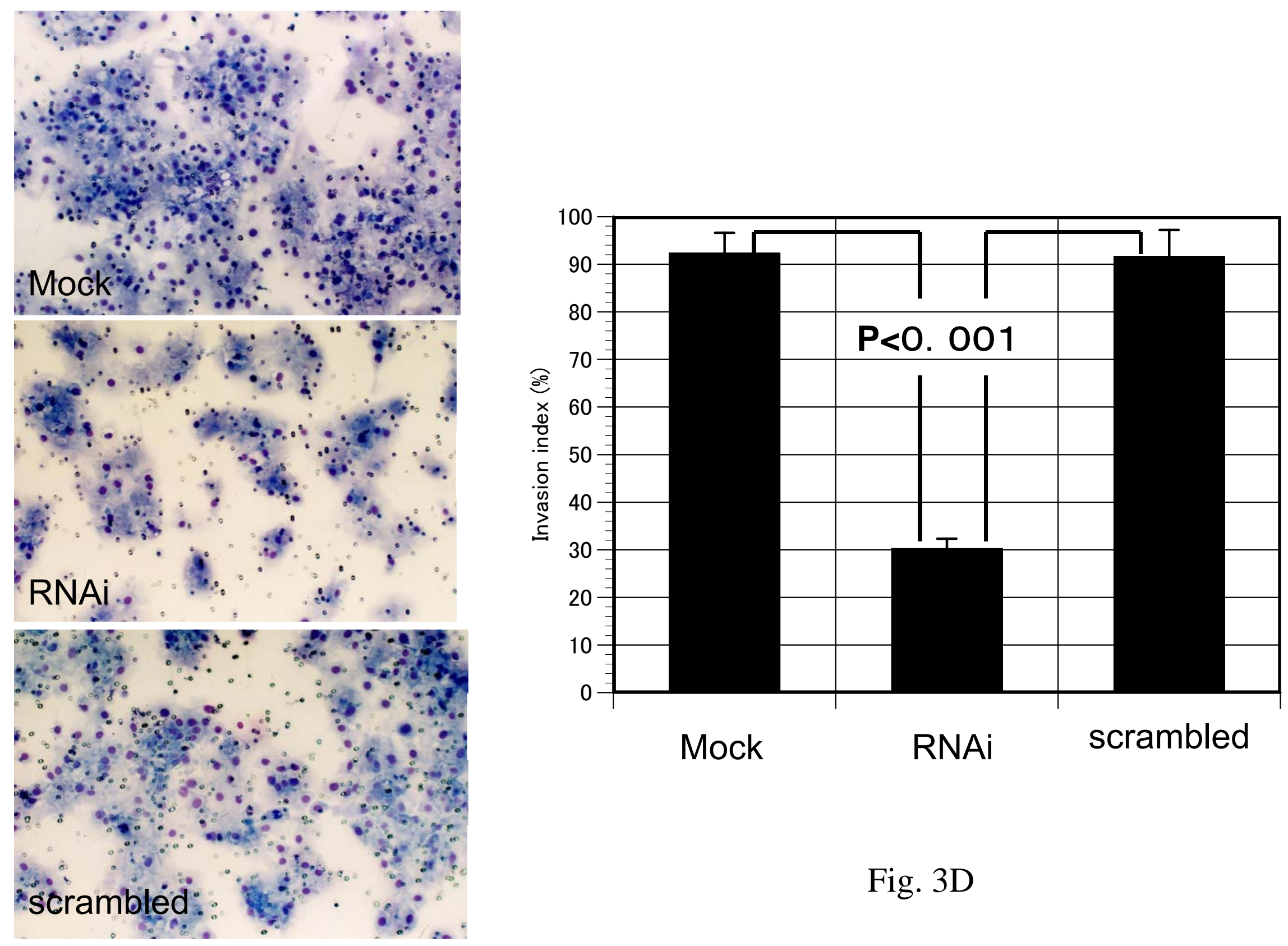

Fig. 3D 


\section{Mock RNAi Scrambled}

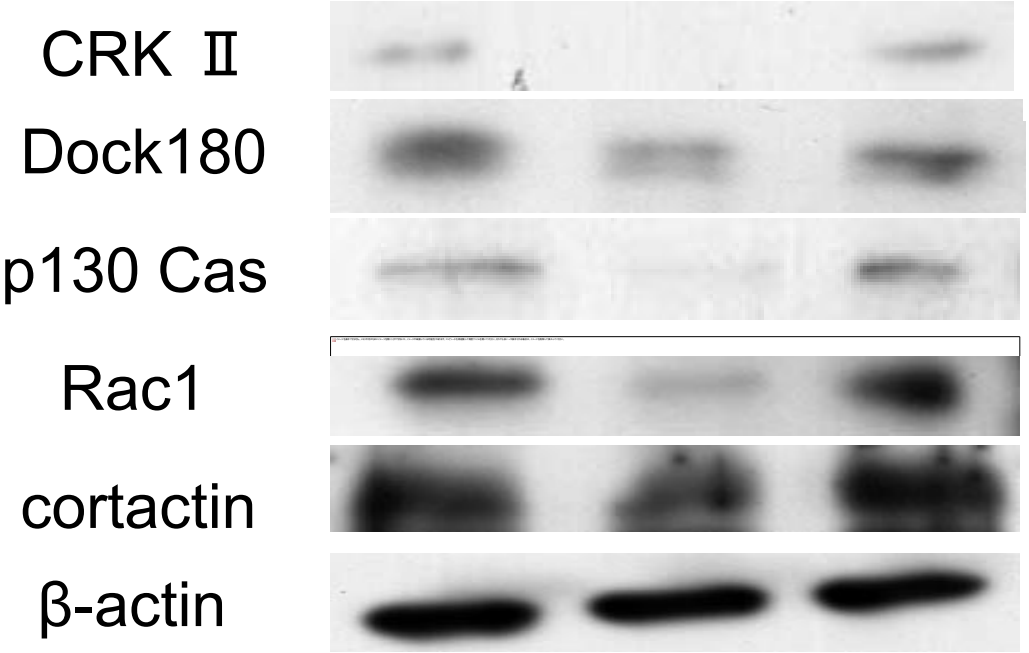

Fig. 4 